\title{
SISTEM PENDUKUNG KEPUTUSAN PINJAMAN KREDIT DENGAN METODE ANAL YTICAL NETWORK PROCESS
}

\author{
Sandi \\ PT GLOSTAR INDONESIA \\ sandi.benzoat@gmail.com \\ Jl. Pelabuhan II No.KM, RW.5, Bojong, Kec. Cikembar, Sukabumi Regency, Jawa Barat 43157 \\ * Korespondensi: e-mail: sandi.benzoat@gmail.com
}

\begin{abstract}
ABSTRAK
Tabungan dan koperasi pinjaman P2K3 adalah koperasi yang melakukan operasi seperti koperasi pada umumnya, koperasi ini melayani tabungan dan pinjaman dari anggota koperasi selain anggota koperasi tidak dapat menyimpan atau meminjam uang dari koperasi. Sejauh ini koperasi telah mengalami masalah dalam hal pelunasan pinjaman dari anggota koperasi yang telah dipinjam, mengakibatkan kemacetan dalam pembayaran dan menghambat perkembangan koperasi itu sendiri. Oleh karena itu, perlu untuk membuat sebuah sistem untuk membantu koperasi memberikan pinjaman kelayakan, sistem yang dirancang adalah pinjaman koperasi sistem dukungan keputusan kredit dengan proses analisis jaringan (ANP) metode, menggunakan metode ANP, mudahmudahan dapat memberikan keputusan yang tepat pada pinjaman kelayakan sehingga tidak ada kemacetan dalam pembayaran angsuran karena metode ANP dapat mengakomodasi hubungan antara kriteria atau alternatif , Adapun kriteria yang digunakan adalah keuangan dan Ketenagakerjaan. Perancang sistem pendukung keputusan menggunakan bahasa program PHP dan basis data MySQL sehingga mudah diakses di jaringan lokal atau internet.
\end{abstract}

Keywords: Koperasi Tabungan dan Pinjaman, Kredit, Analytical Network Process, PHP dan MySQL.

\begin{abstract}
ABSCTRACT
Savings and loan cooperatives P2K3 are cooperatives that conduct operations such as cooperatives in general, these cooperatives serve savings and loans from members of cooperatives in addition to members of the cooperative can not save or borrow money from cooperatives. So far the cooperatives have experienced problems in terms of loan repayment from members of cooperatives that have borrowed, resulting in congestion in payments and hampering the development of the cooperative itself. Therefore, it is necessary to create a system to help the cooperative provide loan feasibility, the system designed is a cooperative loan credit decision support system with the analytical network process (ANP) method, using the ANP method, hopefully it can provide the right decision on the lending feasibility so there is no congestion in installment payments because ANP method can accommodate the linkages between criteria or alternatives, as for the criteria used are finance and employment. Decision support system designers use the PHP program language and MySQL database so that it is easy to access on a local network or the internet.
\end{abstract}

Keywords: Savings and Loan Cooperative, Credit, Analytical Network Process, PHP and MySQL.

\section{PENDAHULUAN}

\subsection{Latar Belakang}

Koperasi simpan pinjam adalah koperasi yang bergerak dalam lapangan usaha pembentukan modal melalui tabungan-tabungan para anggota secara teratur dan terus-menerus untuk kemudian dipinjamkan kepada para anggota dengan cara mudah, murah, cepat dan tepat untuk tujuan produktif dan kesejahteraan [1].

Dari data koperasi yang di ambil dari tahun 2014 - 2018 terdapat penunggakan pembayaran anggota yang melakukan pinjaman uang kepada koperasi, hampir 60\% anggota koperasi melakukan penunggakan pembayaran sehingga koperasi sangat terhambat untuk berkembang, kalau ini didiamkan tanpa mencari solusi yang efektif koperasi simpan pinjam ini bisa-bisa terjadi dwon dan tidak dapat berkembang dan hal yang paling buruknya koperasi ini bisa ditutup tidak dapat melakukan kegiatan operasional seperti 
JURSISTEKNI (Jurnal Sistem Informasi dan Teknologi Informasi) Vol 2, No. 2, Mei 2020: Hal 25 - 38

ISSN. P: 2715-1875, E: 2715-1883

biasa lagi karna terjadi kerugian, Tahapan pemberian pinjaman pada koperasi ini sangat mudah hanya dengan wawancara saja calon nasabah dengan kepala koperasi tanpa adanya penilaian dengan data yang objektif .

Oleh karna itu perlu dilakukan penelitian untuk menentukan titik masalah terjadi penunggakan pembayaran pinjaman, dikarnakan banyak terjadi penunggakan pembayaran pinjaman, dengan berbagai kasus permasalahan yang sudah terjadi bagaimana Koperasi Simpan pinjam p2k3 PT.XYZ bisa memberikan pinjaman dengan sangat tepat dan akurat.

Dalam mengatasi masalah-masalah tersebut, penulis akan membuat sistem pendukung keputusan dengan menerapkan metode perengkingan yang dapat memberikan kemudahan dalam menentukan prioritas pemberian pinjaman kredit anggota koperasi. Metode yan diterapkan adalah metode ANP (Analytic Network Process).

Metode ANP ini adalah salah satu metode yang mampu merepresentasikan tingkat kepentingan berbagai pihak dengan mempertimbangkan saling keterkaitan antar kriteria dan sub kriteria yang ada. Model ini merupakan pengembangan dari AHP sehingga kompleksitasnya lebih dibanding metode AHP [2]. Dalam metode ini memerlukan interaksi dan ketergantungan dengan menggunakan network. ANP mengijinkan adanya interaksi dan umpan balik dari elemen-elemen dalam kriteria (inner dependence) dan antar kriteria (outer dependence), ANP merupakan metode pemecahan suatu masalah yang tidak terstruktur dan adanya ketergantungan hubungan antar elemennya [3], metode ini bisa menghasilkan suatu keputusan yang sangat akurat untuk memberikan keputusan dan juga pihak koperasi bisa melakukan tindakan preventif sebelum terjadi penunggakan pembayaran.

Dengan menggunakan metode ANP Sistem pendukung keputusan ini bisa membantu kepala koperasi untuk memberikan keputusan kepada anggota koperasi yang mengajukan pinjaman, layak atau tidaknya untuk diberikan pinjaman.

\subsection{Rumusan Masalah}

1. Bagaiamana Metode ANP digunakan untuk Sistem Pendukung Keputusan Koperasi Simpan Pinjam P2K3 PT.XYZ ?

2. Berapa nilai bobot masing masing kriteria dan alternatif?

3. Seberapa penting sistem pendukung keputusan dapat memberikan informasi serta membantu pihak kepala koperasi dalam memberikan pinjaman kredit?

\subsection{Manfaat Penelitian}

1. Supaya bisa memberikan penilaian terhadap anggota koperasi siapa yang layak menerima pinjaman dari koperasi.

2. Bisa digunakan sebagai dasar pengambilan keputusan yang tidak terstruktur untuk mendukung proses pemberian pinjaman diKoperasi P2K3 PT.XYZ.

3. Agar bisa digunakan oleh kepala koperasi untuk membantu menentukan kelayakan pemberian pinjaman kredit pada anggota koperasi P2K3 PT.XYZ.

\subsection{Tujuan Penelitian}

1. Untuk mengetahui penerapan metode ANP digunakan dalam Sistem Pendukung Keputusan.

2. Untuk mengetahui nilai bobot masing masing kriteria dan alternatif.

3. Untuk mengetahui seberapa penting sistem yang dibuat untuk kepala koperasi dalam memberikan keputusan pinjaman kredit.

\section{TINJAUAN PUSTAKA}

\subsection{Penelitian Terkait}

Pertama penelitian yang dilakukan oleh Khairil Adnan, Sandy Eka Permana, Tineka Handayani (2013), yang berjudul "Sistem Pendukung Keputusan Penentuan Pemberian Pinjaman Uang Dengan Metode AHP (Analytic Hierarchy Process) Di Koperasi Simpan Pinjam Eka Mulya”, permasalahan yang tejadi Selama ini untuk dapat menentukan siapa saja yang berhak mendapatkan pinjaman uang dengan 
JURSISTEKNI (Jurnal Sistem Informasi dan Teknologi Informasi) Vol 2, No. 2, Mei 2020: Hal 25 - 38

ISSN. P: 2715-1875, E: 2715-1883

kegiatan administrasi yang meliputi kegiatan analisis secara kuantitatif dan kualitatif memerlukan waktu yang agak lama karena data yang disajikan tidak berbentuk nilai, dengan kriteria Character, Capacity, Capital, Collateral, Condition dengan dataset 23 menghasilkan Presentase tingkat kevalidasian dari uji program yang telah Koperasi Eka Mulya adalah 65,2\%. Hal ini didapatkan berdasarkan uji program Sistem Pendukung Keputusan Kelayakan pemberian pinjaman uang dengan Metode AHP yang disesuaikan dengan uji penilaian yang dilakukan oleh Koperasi Eka Mulya [4].

Kedua, penelitian yang dilakukan oleh Agung Triayudi, Fajar Setiawan Hidayat (2016)yang berjudul "Sistem Pendukung Keputusan Penentuan Penerima Pinjaman Modal Dana Bergulir Koperasi Simpan Pinjam Pada Diskoperindag Kabupaten Serang Menggunakan Metode Topsis". permasalahan yang tejadi karena Membutuhkan waktu yang lama untuk penyeleksiannya dan belum ada sistem aplikasi yang mendukung untuk penentuan pinjaman modal dana bergulir koperasi simpan pinjam. Dengan kriteria Berbadan Hukum, Jumlah Anggota, Lama Berdiri, Kisaran Modal, RAT, Status Koperasi, Menghasilkan perangkingan nilai tertinggi ke rendah dan dengan menggunakan rentang nilai $0.65-1$ untuk menentukan koperasi simpan pinjam yang mendapat pinjaman modal dana bergulir tersebut [5].

Ketiga penelitian yang dilakukan oleh Agusta Praba Ristadi Pinem, Prind Triajeng Pungkasanti, Edi Widodo (2017) yang berjudul "Implementasi Profile Matching Untuk Pemberian Kredit Kedua Pada Koperasi Simpan Pinjam". permasalahan yang tejadi Koperasi memiliki program simpan pinjam yang ditujukan kepada nasabah yang ingin melakukan peminjaman atau kredit. Dalam menentukan kelayakan pemberian kredit, ada beberapa kriteria yang menjadi tolak ukur sehingga menghindari resiko kredit macet. Penulis menggunakan kriteria Riwayat nasabah, Nilai jaminan, Nilai kredit, Jangka waktu kredit, Usia Dengan Dataset 20 nasabah, menghasilkan data sekunder yang diperoleh dari observasi sistem informasi simpan pinjam koperasi selanjutnya data diolah untuk mendapatkan data yang utuh terkait dengan lima aspek yang digunakan. Pada proses perhitungan manual dengan metode profile matching menggunakan 20 data nasabah yang sudah pernah melakukan peminjaman sebelumnya. Nasabah Nurarifin menjadi nasabah dengan nilai tertinggi [6].

Keempat, penelitian yang dilakukan oleh Igon, Irya Wisnubhadra, B.Yudi Dwiandiyanta (2014), yang berjudul "Perancangan Sistem Pendukung Keputusan Dengan Metode Fuzzy Analytic Hierarchy Process Dalam Penyeleksian Pemberian Kredit" Permasalahan muncul pada ketidak tepatan penilaian yang dilakukan oleh general manager sebagai pengambil keputusan dalam melakukan penyeleksian kepada anggota, hal ini disebabkan karena jumlah anggota yang mengajukan pinjaman sangat banyak dan pengambilan keputusan yang dilakukan bersifat subjektif, penulis menggunakan kriteria Kemampuan, Kondisi Ekonomi, Jaminan, Modal dan Karakter, menghasilkan Bahwa ketiga anggota (A4, A2 dan A1) memiliki $\mathrm{n}$ ilai bobot dengan peringkat 1,2 dan 3. Dengan demikian ketiga anggota tersebut layak menerima pinjaman dari Kopdit Remaja Hokeng. Akan tetapi hasil keputusan ini hanya sebagai bahan pertimbangan untuk membantu Ketua Kopdit dalam mengambil keputusan. Keputusan akhir berada pada Ketua Kopdit Remaja Hokeng [7].

\subsection{Koperasi Simpan Pinjam}

Konsep dari koperasi ini adalah anggota yang menyimpan uangnya di koperasi akan mendapatkan imbalan menabung dan anggota yang melalukan peminjaman akan dikenakan jasa. Jasa yang dikenakan oleh anggota yang meminjam adalah berupa bunga kecil ketika melakukan pembayaran terhadap uang yang dipinjamnya. Oleh sebab itu koperasi itu berasal dari anggota, oleh anggota dan hasilnya pun akan dikembalikan untuk anggota [5].

\subsection{Kredit}

Menurut Teguh Pudjo Mulyono,Kredit adalah suatu penyerahan uang atau tagihan yang dapat dipersamakan dengan itu, berdasarkan persetujuan atau kesepakatan pinjam meminjam antara Bank dengan pihak lain yang mewajibkan pihak peminjam untuk melunasi hutangnya setelah jangka waktu tertentu dengan bunga jumlah imbalan atau pembagian hasil keuntungan [8].

\subsection{Sistem Informasi Manajemen}

SIM (sistem informasi manajemen) dapat didefenisikan sebagai kumpulan dari interaksi sistemsistem informasi yang bertanggung jawab mengumpulkan dan mengolah data untuk menyediakan 
JURSISTEKNI (Jurnal Sistem Informasi dan Teknologi Informasi) Vol 2, No. 2, Mei 2020: Hal 25 - 38

ISSN. P: 2715-1875, E: 2715-1883

informasi yang berguna untuk semua tingkatan manajemen di dalam kegiatan perencanaan dan pengendalian [9].

\subsection{Sistem Pendukung Keputusan}

Sistem pendukung keputusan (decision support system atau DSS) adalah sistem informasi berbasis komputer yang menyediakan dukunganinformasi interaktif bagi manajer dan praktisi bisnis selamam proses pengambilan keputusan. Sistem pendukung keputusan menggunakan (1) model analitis, (2) database khusus, (3) penilaian dan pandangan pembuat keputusan, dan (4) proses permodelan berbasis computer yang interaktif untuk mendukung pembuatan keputusan bisnis yang semiterstruktur dan tak terstruktur [10].

Sistem Pendukung Keputusan (SPK) atau Decision Support System (DSS) merupakan suatu pendekatan (atau metodologi) untuk mendukung pengambilan keputusan. DSS menggunakan Computer Base Information System (CBIS) yang fleksibel, interaktif, dan dapat diadaptasi, yang dikembangkan untuk mendukung solusi bagi masalah manajemen spesifik yang tidak terstruktur [11].

\subsection{Metode Analytical Network Process (ANP)}

ANP adalah teori umum pengukuran relative yang digunakan untuk menurunkan rasio prioritas komposit dari skala rasio individu yang mencerminkan pengukuran relative dari pengaruh elemen-elemen yang saling berinteraksi berkenaan dengan kriteria control [12].

Untuk mendapatkan bobot dari setiap elemen ANP digunakan kuisioner perbandingan berpasangan yang di ambil dari preperensi para pakar dan kemudian diolah dengan Software Superdecision, dalam pengambilan keputusan sering dihadapkan pada beberapa faktor yang menjadi pertimbangan yang terstruktur kompleks terkait satu sama lain. Metode ANP mampu mengakomodir persoalan [13].

\subsection{KerangkaPemikiran}

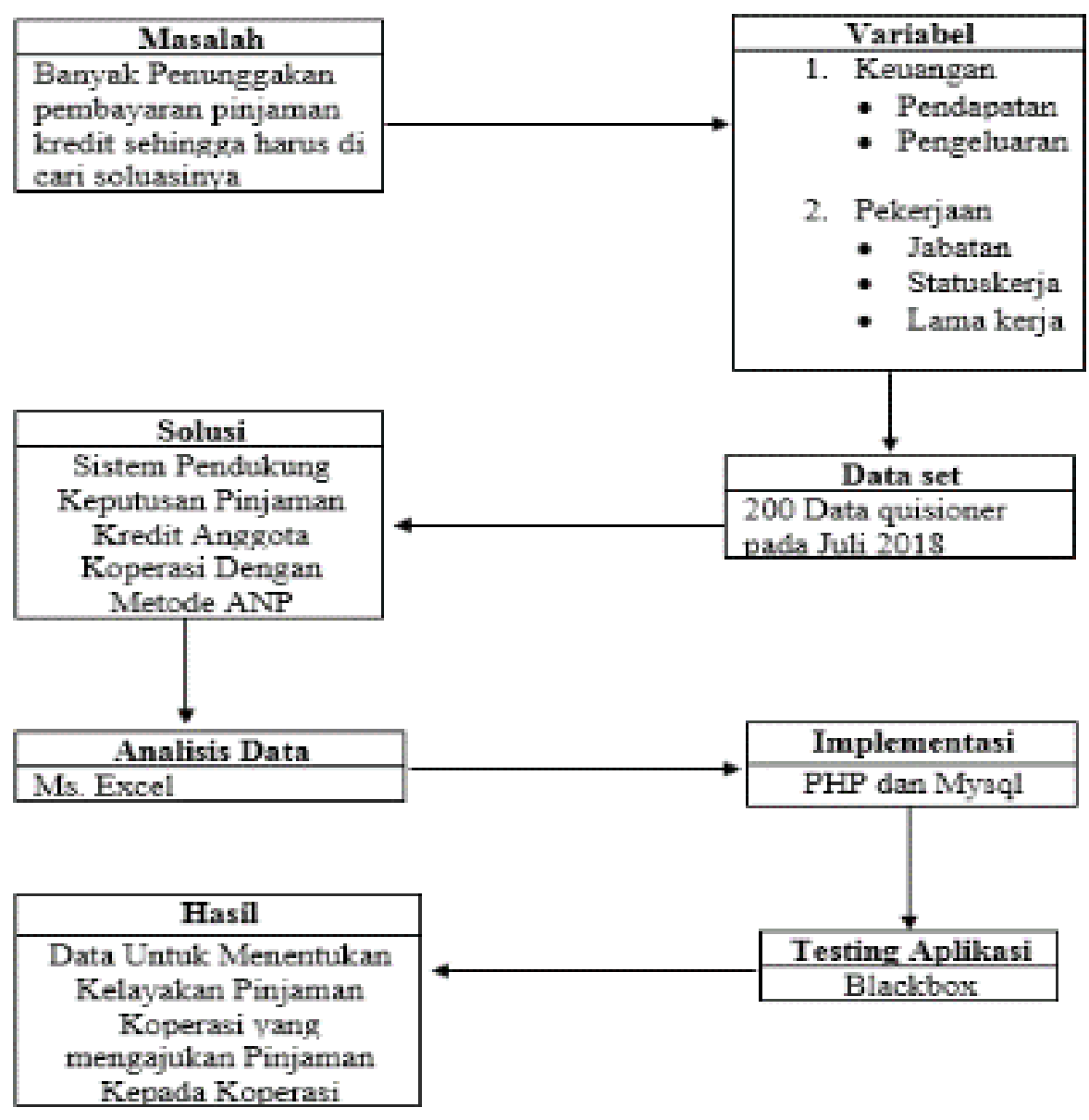

Gambar 1. Kerangka Berpikir

Copyright@2019.PRODI SISTEM INFORMASI UNIVERSITAS NUSA PUTRA 


\section{METODOLOGI PENELITIAN}

\subsection{Metode Pengumpulan Data}

Pada tahap ini dilakukan pengumpulan data yang dibutuhkan untuk membangun sistem pendukung keputusan, layak atau tidaknya anggota koperasi menerima pinjaman dari koperasi. Semua tahap pada proses pengumpulan data tersebut diperoleh dari:

1. Wawancara

2. Kuisioner

3. Tinjauan Pustaka

\subsection{Data kriteria dan Sub Kriteria}

Tabel 1. Data kriteria dan Sub Kriteria

\begin{tabular}{|c|c|c|c|c|}
\hline No & Kriteria & $\begin{array}{c}\text { Nama } \\
\text { Kriteria }\end{array}$ & Sub kriteria & $\begin{array}{c}\text { Nama Sub } \\
\text { Kriteria }\end{array}$ \\
\hline 1 & C1 & Keuangan & E11 & Pendapatan \\
\cline { 4 - 5 } & & E12 & Pengeluaran \\
\hline 2 & \multirow{2}{*}{ C2 } & \multirow{2}{*}{ Pekerjaan } & E21 & Jabatan \\
\cline { 4 - 5 } & & & E22 & Lama Kerja \\
\cline { 3 - 4 } & & & E23 & Status Kerja \\
\hline
\end{tabular}

\subsubsection{Membentuk Perbandingan Berpasangan}

1. Perbandingan antar Kriteria

2. Perbandingan berpasangan SubKriteria dan menguji konsisten ration

3. Perbandingn tingkat kepentingan alternatif terhadap sub pekerjaan

4. Perbandingan ini dihasilkan dari perbandingan kepentingan setiap alternatif terhadap subkriteria Pekerjaan

5. Perbandingn tingkat kepentingan alternatif terhadap sub Keuangan

6. Perbandingan ini dihasilkan dari perbandingan kepentingan setiap alternatif terhadap subkriteria keuangan

\subsubsection{Menghitung bobot elemen}

Untuk menghitung nilai bobot elemen di lakukan perkalian nilai eigen vektor dengan jumlah setiap kolom dengan rumus dibawah ini:

$\lambda m a k s=($ nilai eigen $1 \times$ jumlah kolom 1$)+($ nilai eigen $2 \times$ jumlah kolom 2$) \ldots n$.

\subsubsection{Menghitung indeks konsistensi CI dan CR}

Indeks konsistensi diperoleh dari hasil nilai bobot elemen yang di hitung dengan rumus Consitensi Index (CI): di bawah ini:

Rumus: $\mathrm{CI}=(\lambda$ maks-n $) / \mathrm{n}-1$

Dimana: $\quad \mathrm{n}=$ banyaknya elemen

$C I=$ Consistency Index

$\lambda$ maks = nilai eigen terbesar

Setelah mendapatkan nilai CI, untuk mendapatkan nilai Consistensi Rasio $(C R)$ di gunakan nilai random indeks (RI), Dimana RI adalah nilai yang di dapatkan dari hasil bobot elemen lalu di pilih sesuai dengan ketentuan random index pada tabel 3.23 sebagai berikut ini:

Tabel 2. Random Index

\begin{tabular}{|l|l|l|l|l|l|l|l|l|l|l|}
\hline $\mathbf{N}$ & 1 & 2 & 3 & 4 & 5 & 6 & 7 & 8 & 9 & 10 \\
\hline $\mathbf{R I}$ & 0 & 0 & 0.58 & 0.90 & 1.12 & 1.24 & 1.32 & 1.41 & 1.45 & 1.49 \\
\hline
\end{tabular}

Lalu di lakukan perhitungan dengan rumus Consistensi Rasio $(C R)$ sebagi berikut: 
JURSISTEKNI (Jurnal Sistem Informasi dan Teknologi Informasi) Vol 2, No. 2, Mei 2020: Hal 25 - 38

ISSN. P: 2715-1875, E: 2715-1883

Rumus: CR = CI/IR

Dimana : $C R=$ Consistency Ratio

$C I=$ Consistency Index

Konsistensi ratio ini di gunakan Untuk menentukan apakah konfigurasi matriks yang dibuat konsisten atau tidak. Artinya bahwa jika nilai $\mathrm{CR} \leq 0.1$ maka matrik yang dibuat konsisten, tetapi jika sebaliknya maka konfiguasi matrik harus dirubah kembali dan menyusun konfigurasi matriks yang baru sampai nilai $\mathrm{CR} \leq 0.1$

\subsubsection{Membuat Super Matriks}

1. Tahap super matriks tanpa bobot (unweighted super matrix).

Supermatriks ini di hasilkan dari nilai eigen vektor yang di dapatakan dari matriks perbandingan kriteria, subkriteria dan alternatif.

2. Tahap super matriks terbobot (weighted super matrix).

Supermatriks ini hasil dari perkalian nilai unweight supermatriks dengan nilai eigent vektor perbandingan kriteria.

3. Tahap super matriks batas (limiting super matrix).

Limit super matrik ini diperoleh dengan mengkuadratkan nilai weight super matriks terus menerus sampai nilai pada satu baris bernilai sama, Limit super matriks ini juga merupakan hasil akhir untuk melakukan perengkingan.

\subsection{Analisa Kebutuhan Software}

\subsubsection{Usecase}

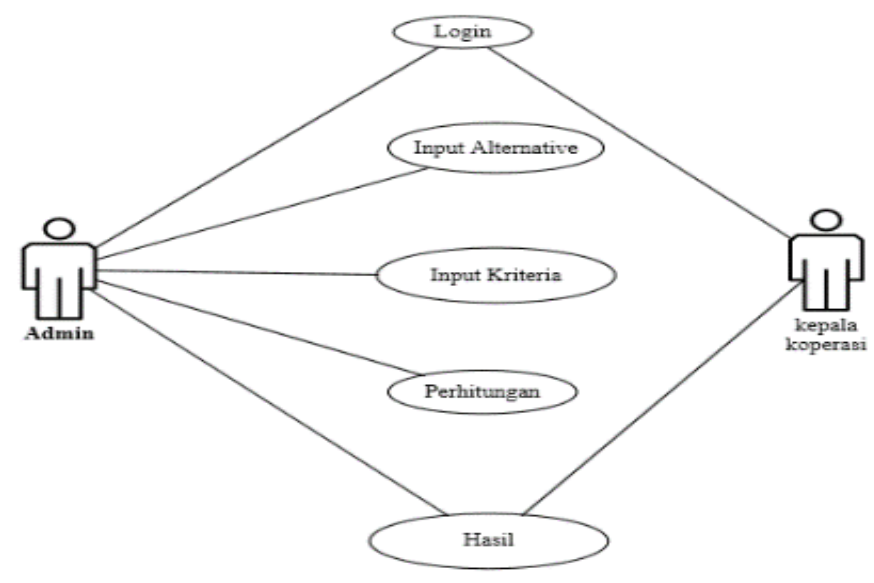

Gambar 2. Usecase perancangan

\subsubsection{Class Diagram}

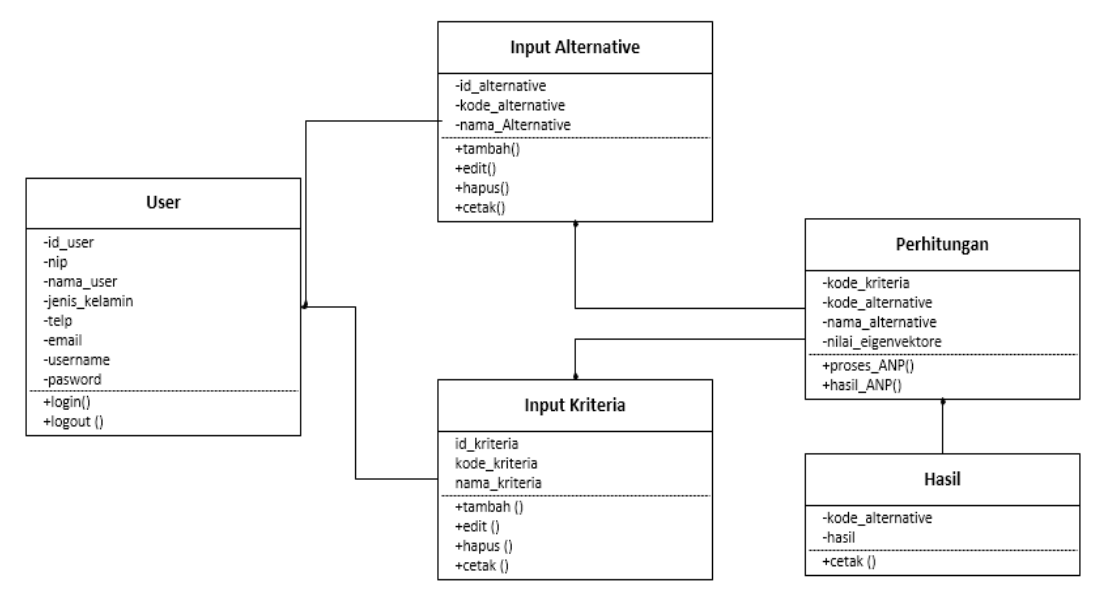

Gambar 3. Class diagram 
JURSISTEKNI (Jurnal Sistem Informasi dan Teknologi Informasi) Vol 2, No. 2, Mei 2020: Hal 25 - 38 ISSN. P: 2715-1875, E: 2715-1883

Gambar yang tertera diatas terdapat 5 objek yang terdiri dari data user, input alternatif, input krieria, perhitungan dan hasil. Dimana kepala koperasi hanya bisa mengakses login dan hasil. Sedangkan admin adalah pengelola dari semua sistem yang terdapat pada aplikasi tersebut.

\section{BAB IV. HASIL DAN PEMBAHASAN}

\subsection{Hasil}

\subsubsection{Data sampel kuisioner}

Data kuisioner digunakan untuk mendapatkan nilai bobot setiap alternatif yang berhubungan dengan setiap kriteria-kriteria yang sudah di tetapkan oleh pihak koperasi pada metode ANP.

\subsubsection{Perhitungan Manual dengan Metode ANP}

Setelah melakukan perbandingann kriteria, subkriteria dan alternatve. selanjutnya dilakukan perhitungan matriks perbanndingan kriteria sepert dibawah ini.

\subsubsection{Matrik Perbandingan Berpasangan Kriteria.}

Tabel 3. Matrik Perbandingan kriteria terhadap keuangan

\begin{tabular}{|l|l|l|}
\hline Kriteria & Alternatif & Pekerjaan \\
\hline ALT & 1 & 0.2 \\
\hline Pekerjaan & 5 & 1 \\
\hline Jumlah & 6 & 1.2 \\
\hline
\end{tabular}

Jumlah kolom kedua $: 5+1=6$

Jumlah kolom pertama : $1+1 / 5=1.2$

Eigen vectore untuk baris pertama $: \frac{\left(\frac{1 / 5}{1.2}+\frac{1}{6}\right)}{2}=0,166$

Eigen vectore untuk baris kedua $: \frac{\left(\frac{1}{1.2}+\frac{5}{6}\right)}{2}=0,833$

Tabel 4. Nilai Eigen vektore matrik perbandingan kriteria terhadap keuangan

\begin{tabular}{|l|l|l|l|}
\hline Kriteria & Alternatif & Pekerjaan & E.Vektore \\
\hline ALT & 1 & 0.2 & 0.166 \\
\hline Pekerjaan & 5 & 1 & 0.833 \\
\hline Jumlah & 6 & 1.2 & \\
\hline
\end{tabular}

Nilai $\lambda$ mak : 6+0.166) $+(1.2 \times 0.833)=2$

Nilai CI $:\left(\frac{\lambda \mathrm{mak}-\mathrm{n}}{n-1}\right)$

$\mathrm{CI}=\left(\frac{2-2}{2-1}\right)=\frac{0}{1}=0$

Nilai CR: $\frac{C I}{R I}$

$\mathrm{CR}=\frac{0}{0}=0$

Nilai konsisten karrna $\mathrm{CR} \leq 0.1$

\subsubsection{Matrik perbandingan berpasangan subkriteria dan menguji konsisten ratio}

Tabel 5. Matrik Perbandingan Berpasangan terhadap pekerjaan

\begin{tabular}{|l|l|l|l|}
\hline Kriteria & Jabatan & Status kerja & Lama kerja \\
\hline Jabatan & 1 & 2 & 2 \\
\hline Status kerja & 0.50 & 1 & 1 \\
\hline
\end{tabular}


JURSISTEKNI (Jurnal Sistem Informasi dan Teknologi Informasi) Vol 2, No. 2, Mei 2020: Hal 25 - 38 ISSN. P: 2715-1875, E: 2715-1883

\begin{tabular}{|l|l|l|l|}
\hline Lama kerja & 0.50 & 1 & 1 \\
\hline Jumlah & 2 & 4 & 4 \\
\hline
\end{tabular}

Jumlah kolom pertama : $1+1 / 2+1 / 2=2$

Jumlah kolom kedua $: 2+1+1=4$

Jumlah kolom ketiga $: 2+1+1=4$

Eigen vectore untuk baris pertama $: \frac{\left(\frac{1}{2}+\frac{2}{4}+\frac{2}{4}\right)}{3}=0,50$

Eigen vectore untuk baris kedua $: \frac{\left(\frac{1 / 2}{2}+\frac{1}{4}+\frac{1}{4}\right)}{3}=0,25$

Eigen vectore untuk baris ketiga $: \frac{\left(\frac{1 / 2}{2}+\frac{1}{4}+\frac{1}{4}\right)}{3}=0,25$

Tabel 6. Nilai eigen vektore Matrik berpasangan pendapatan terhadap pekerjaan

\begin{tabular}{|l|l|l|l|l|}
\hline Kriteria & Jabatan & Status kerja & Lama kerja & e.vektore \\
\hline Jabatan & 1 & 2 & 2 & 0,50 \\
\hline Status kerja & 0,5 & 1 & 1 & 0,25 \\
\hline Lama kerja & 0.5 & 1 & 1 & 0.25 \\
\hline Jumlah & 2 & 4 & 4 & \\
\hline
\end{tabular}

Nilai $\lambda$ mak : $(2 \times 0.50)+(4+0.25)+(4+0.25)=3$

Nilai CI :( $\left.\frac{\lambda \mathrm{mak}-\mathrm{n}}{n-1}\right)$

$\mathrm{CI}=\left(\frac{3-3}{3-1}\right)=\frac{0}{2}=0$

Nilai CR: $\frac{C I}{R I}$

$\mathrm{CR}=\frac{0}{0.58}=0$

Nilai konsisten karna $\mathrm{CR} \leq 0.1$

\subsubsection{Menentukan Nilai Alternatif terhadap kriteria dan subkriteria}

Tabel 7. Matrik Perbandingan Alternatif 1 Eka Terhadap pekerjaan

\begin{tabular}{|l|l|l|l|}
\hline & Jabatan & Lama Kerja & Status kerja \\
\hline Jabatan & 1 & 0.25 & 0.143 \\
\hline Lama Kerja & 4 & 1 & 0.333 \\
\hline Status kerja & 7 & 3 & 1 \\
\hline Jumlah & 12 & 4.25 & 1.47619 \\
\hline
\end{tabular}

Jumlah kolom pertama : $1+4+7=12$

Jumlah kolom kedua $: 0.25+1+3=4.25$

Jumlah kolom ketiga $\quad: 0.143+0.333+1=1.47619$

Eigen vectore untuk baris pertama : $\quad \frac{\left(\frac{1}{12}+\frac{1 / 4}{4.25}+\frac{1 / 7}{1.47}\right)}{3}=0.079644$

Eigen vectore untuk baris kedua $\quad \frac{\left(\frac{4}{12}+\frac{1}{4.25}+\frac{1 / 3}{1.47}\right)}{3}=0.264811$

Eigen vectore untuk baris ketiga $\quad \frac{\left(\frac{7}{12}+\frac{3}{4.25}+\frac{1}{1.47}\right)}{3}=0.655545$ 
JURSISTEKNI (Jurnal Sistem Informasi dan Teknologi Informasi) Vol 2, No. 2, Mei 2020: Hal 25 - 38 ISSN. P: 2715-1875, E: 2715-1883

Tabel 8. Nilai eigen vektore Matrik Perbandingan Alternatif 1 Eka Terhadap pekerjaan

\begin{tabular}{|l|l|l|l|l|}
\hline & Jabatan & Lama Kerja & Status kerja & e.vektore \\
\hline Jabatan & 1 & 0.25 & 0.143 & 0.079644 \\
\hline Lama Kerja & 4 & 1 & 0.333 & 0.264811 \\
\hline Status kerja & 7 & 3 & 1 & 0.655545 \\
\hline Jumlah & 12 & 4.25 & 1.47619 & \\
\hline
\end{tabular}

Nilai $\lambda$ mak : $(12 \times 0.079644)+(4.25 \times 0.264811)+(1.476 \times 0.655545)=3$

Nilai CI :( $\left.\frac{\lambda \mathrm{mak}-\mathrm{n}}{n-1}\right)$

$\mathrm{CI}=\left(\frac{3-3}{3-1}\right)=\frac{0}{2}=0$

Nilai CR: $\frac{C I}{R I}$

$\mathrm{CR}=\frac{0}{0.58}=0$

Nilai konsisten karrna $\mathrm{CR} \leq 0.1$

\subsubsection{SuperMatrik}

1. Unweight Supermatrik

Unweight Supermatrik ini di hasilkan dari nilai eigen vektor yang di dapatakan dari perhitungan matriks perbandingan kriteria, subkriteria dan Alternatif.

Tabel 9. Unweight supermatrik

\begin{tabular}{|c|c|c|c|c|c|c|c|c|c|}
\hline \multicolumn{2}{|c|}{} & \multicolumn{3}{c|}{ ALTERNATIF } & \multicolumn{2}{c|}{ KEUANGAN } & \multicolumn{2}{c|}{ PEKERJAAN } \\
\cline { 3 - 11 } \multicolumn{2}{|c|}{} & A1 & A2 & A3 & E11 & E12 & E21 & E22 & E23 \\
\hline \multirow{3}{*}{ ALTERNATIF } & A1 & 0 & 0 & 0 & 0.333 & 0.250 & 0.200 & 0.142 & 0.333 \\
\cline { 2 - 11 } & A2 & 0 & 0 & 0 & 0.333 & 0.500 & 0.400 & 0.428 & 0.333 \\
\cline { 2 - 11 } & A3 & 0 & 0 & 0 & 0.333 & 0.250 & 0.400 & 0.428 & 0.333 \\
\hline \multirow{3}{*}{ KEUANGAN } & E11 & 0.833 & 0.750 & 0.833 & 0 & 0 & 0.833 & 0.750 & 0.750 \\
\cline { 2 - 10 } & E12 & 0.166 & 0.250 & 0.166 & 0 & 0 & 0.166 & 0.250 & 0.250 \\
\hline \multirow{3}{*}{ PEKERJAAN } & E21 & 0.079 & 0.090 & 0.090 & 0.500 & 0.548 & 0 & 0 & 0 \\
\cline { 2 - 10 } & E22 & 0.264 & 0.454 & 0.454 & 0.250 & 0.210 & 0 & 0 & 0 \\
\cline { 2 - 10 } & E23 & 0.655 & 0.454 & 0.454 & 0.250 & 0.240 & 0 & 0 & 0 \\
\hline
\end{tabular}

2. Weight Supermatrik

Nilai Weight supermatrik ini di hasilkan dari nilai unweight super matriks yang di kalikan denga hasil eigen vektore dengan perbandingan antar kriteria.

Tabel 10. Weight supermatrik

\begin{tabular}{|c|c|c|c|c|c|c|c|c|c|}
\hline \multicolumn{2}{|c|}{} & \multicolumn{3}{|c|}{ ALTERNATIF } & \multicolumn{2}{c|}{ KEUANGAN } & \multicolumn{2}{c|}{ PEKERJAAN } \\
\cline { 2 - 10 } \multicolumn{2}{c|}{} & A1 & A2 & A3 & E11 & E12 & E21 & E22 & E23 \\
\hline \multirow{3}{*}{ ALTERNATIF } & A1 & 0.000 & 0.000 & 0.000 & 0.055 & 0.042 & 0.022 & 0.016 & 0.037 \\
\cline { 2 - 10 } & A2 & 0.000 & 0.000 & 0.000 & 0.055 & 0.083 & 0.044 & 0.047 & 0.037 \\
\cline { 2 - 10 } & A3 & 0.000 & 0.000 & 0.000 & 0.055 & 0.042 & 0.044 & 0.047 & 0.037 \\
\hline \multirow{3}{*}{ KEUANGAN } & E11 & 0.555 & 0.500 & 0.555 & 0.000 & 0.000 & 0.417 & 0.375 & 0.375 \\
\cline { 2 - 10 } & E12 & 0.111 & 0.167 & 0.111 & 0.000 & 0.000 & 0.083 & 0.125 & 0.125 \\
\hline \multirow{3}{*}{ PEKERJAAN } & E21 & 0.026 & 0.030 & 0.030 & 0.415 & 0.455 & 0.000 & 0.000 & 0.000 \\
\cline { 2 - 9 } & E22 & 0.088 & 0.151 & 0.151 & 0.208 & 0.174 & 0.000 & 0.000 & 0.000 \\
\cline { 2 - 9 } & E23 & 0.218 & 0.151 & 0.151 & 0.208 & 0.199 & 0.000 & 0.000 & 0.000 \\
\hline
\end{tabular}


JURSISTEKNI (Jurnal Sistem Informasi dan Teknologi Informasi) Vol 2, No. 2, Mei 2020: Hal 25 - 38

ISSN. P: 2715-1875, E: 2715-1883

3. Limit Supermatrik

Limit supermatrik ini diperoleh dengan mengkuadratkan nilai weight super matriks terus menerus sampai nilai pada satu baris bernilai sama, Limit super matriks ini juga merupakan hasil akhir untuk melakukan perengkingan.

Tabel 11. Limit supermatrik

\begin{tabular}{|c|c|c|c|c|c|c|c|c|c|}
\hline & \multicolumn{3}{|c|}{ ALTERNATIF } & \multicolumn{2}{|c|}{ KEUANGAN } & \multicolumn{3}{|c|}{ PEKERJAAN } \\
\hline & & A1 & A2 & A3 & E11 & E12 & E21 & E22 & E23 \\
\hline \multirow{3}{*}{ ALTERNATIF } & A1 & 0.001 & 0.001 & 0.001 & 0.001 & 0.001 & 0.001 & 0.001 & 0.001 \\
\hline & $\mathrm{A} 2$ & 0.040 & 0.040 & 0.040 & 0.040 & 0.040 & 0.040 & 0.040 & 0.040 \\
\hline & A3 & 0.002 & 0.002 & 0.002 & 0.002 & 0.002 & 0.002 & 0.002 & 0.002 \\
\hline \multirow{2}{*}{ KEUANGAN } & E11 & 0.170 & 0.170 & 0.170 & 0.170 & 0.170 & 0.170 & 0.170 & 0.170 \\
\hline & E12 & 0.010 & 0.010 & 0.010 & 0.010 & 0.010 & 0.010 & 0.010 & 0.010 \\
\hline \multirow{3}{*}{ PEKERJAAN } & E21 & 0.029 & 0.029 & 0.029 & 0.029 & 0.029 & 0.029 & 0.029 & 0.029 \\
\hline & E22 & 0.005 & 0.005 & 0.005 & 0.005 & 0.005 & 0.005 & 0.005 & 0.005 \\
\hline & E23 & 0.043 & 0.043 & 0.043 & 0.043 & 0.043 & 0.043 & 0.043 & 0.043 \\
\hline
\end{tabular}

RANGKING: R1 $=0.040$ Alternatif 2 Iyus

$$
\begin{aligned}
& \text { R2 }=0.002 \text { Alternatif } 3 \text { Yuli } \\
& \text { R3 }=0.001 \text { Alternatif } 1 \text { Eka }
\end{aligned}
$$

Dari hasil perhitungan secara matematis dengan metode ANP maka anggota yang mengajukan pinjaman atas nama iyus layak diberikan pinjaman karna menurut hasil perhitungan manual, Alternatif 2 atas nama iyus mendapatkan nilai limit 0.040 , paling besar diantara nilai limit Alternatif lain yaitu atas nama Yuli mendapatkan nilai limit 0.002 dan atas nama eka mendapatkan nilai limit 0.001 .

\subsubsection{Implementasi}

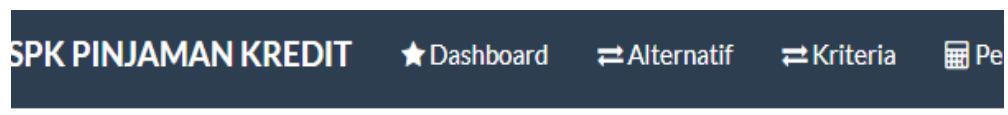

$\begin{array}{lllll}\text { Perhitungan } 1 & \text { Perhitungan } 2 & \text { Perhitungan } 3 & \text { Perhitungan } 4 & \text { Perhitun }\end{array}$

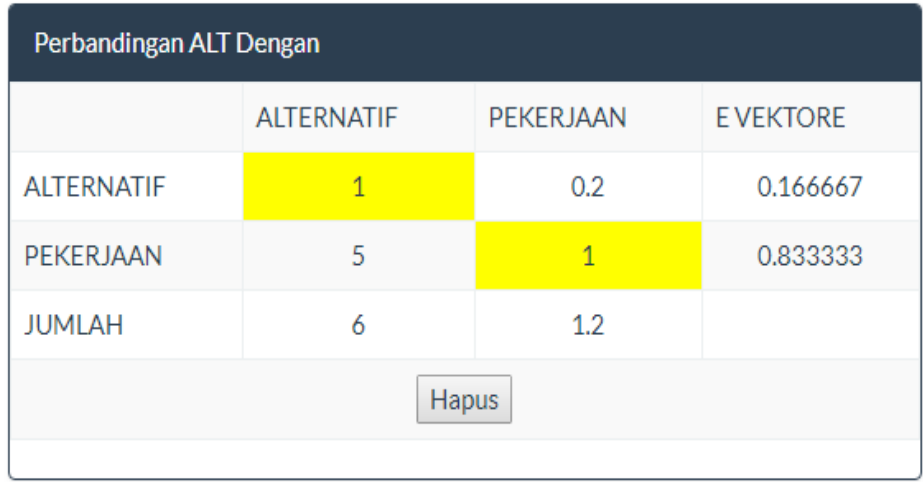

Gambar 4. Perbandingan antar kriteria

Dalam gambar diatas, perhitungan Perbandingan antar kriteria yang dimana nilai eigen vektore digunakan untuk mendapatkan nlai berbobot dengan cara melakukan perkalian dengan semua nilai yang tidak berbobot (Unweight Supermatrik) yang dihasilkan dari semua perbandingan subkriteria dan Alternatif, untuk mendapatkan nilai berbobot (Weight Supermatrik). 
JURSISTEKNI (Jurnal Sistem Informasi dan Teknologi Informasi) Vol 2, No. 2, Mei 2020: Hal 25 - 38

ISSN. P: 2715-1875, E: 2715-1883

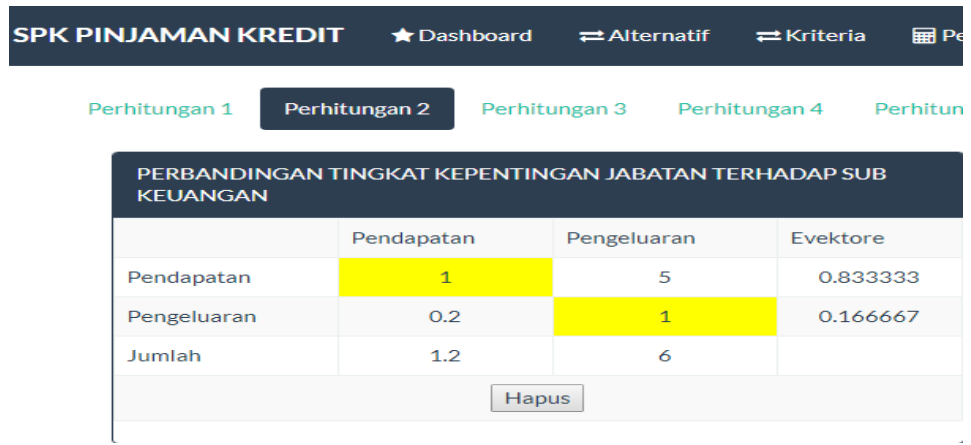

Gambar 5. Perbandingan antar subkriteria

Pada gambar 5 perhitungan perbandingan tingkat kepentingan jabatan terhadap subkeuangan, tinggal memasukan nilai kepentingan masing masing subkriteria pada tabel yang kosong kemudian klik hitung lalu nanti akan menghasilkan nilai e.vektore (eigen vektore).

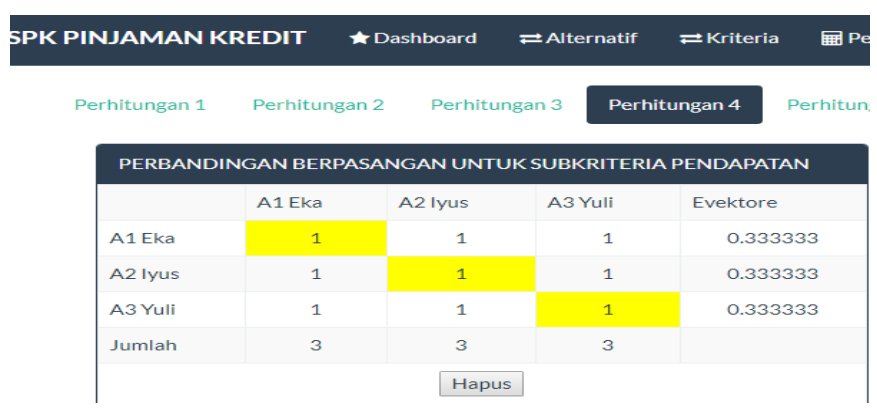

Gambar 6. Perbandingan subkriteria terhadap Alternatif

\begin{tabular}{|c|c|c|c|c|c|c|c|c|c|}
\hline \multicolumn{10}{|c|}{ LIMIT SUPER MATRIK } \\
\hline & & \multicolumn{3}{|c|}{ ALTERNATIF } & \multicolumn{2}{|c|}{ KEUANGAN } & \multicolumn{3}{|c|}{ PEKERJAAN } \\
\hline & & A1 & A2 & A3 & E11 & E12 & E21 & E22 & E23 \\
\hline \multirow[t]{3}{*}{ ALTERNATIF } & A1 & 0.001 & 0.001 & 0.001 & 0.001 & 0.001 & 0.001 & 0.001 & 0.001 \\
\hline & A2 & 0.040 & 0.040 & 0.040 & 0.040 & 0.040 & 0.040 & 0.040 & 0.040 \\
\hline & A3 & 0.002 & 0.002 & 0.002 & 0.002 & 0.002 & 0.002 & 0.002 & 0.002 \\
\hline \multirow[t]{2}{*}{ KEUANGAN } & E11 & 0.170 & 0.170 & 0.170 & 0.170 & 0.170 & 0.170 & 0.170 & 0.170 \\
\hline & E12 & 0.010 & 0.010 & 0.010 & 0.010 & 0.010 & 0.010 & 0.010 & 0.010 \\
\hline \multirow[t]{3}{*}{ PEKERJAAN } & E21 & 0.029 & 0.029 & 0.029 & 0.029 & 0.029 & 0.029 & 0.029 & 0.029 \\
\hline & E22 & 0.005 & 0.005 & 0.005 & 0.005 & 0.005 & 0.005 & 0.005 & 0.005 \\
\hline & E23 & 0.043 & 0.043 & 0.043 & 0.043 & 0.043 & 0.043 & 0.043 & 0.043 \\
\hline
\end{tabular}

Gambar 7. Nilai Limit supermatrik

Gambar 7 adalah nilai limit supermatrik, dari nilai limit ini dilakukan perengkingan terhadap Alternatif yang dibandingkan, karna nilai limit supermatrik adalah proses akhir mendapatkan nilai bobot.

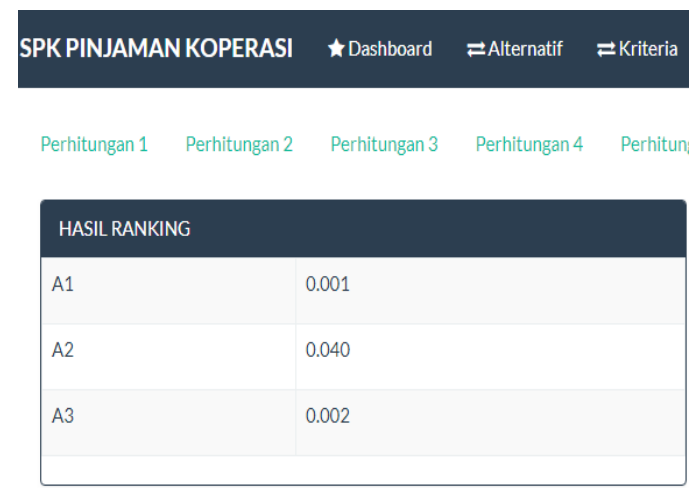

Gambar 8. Hasil Perengkingan

Copyright@2019. PRODI SISTEM INFORMASI UNIVERSITAS NUSA PUTRA 
JURSISTEKNI (Jurnal Sistem Informasi dan Teknologi Informasi) Vol 2, No. 2, Mei 2020: Hal 25 - 38 ISSN. P: 2715-1875, E: 2715-1883

\subsection{Pembahasan}

Hasil dari pengisian kuisioner nasabah yang mengajukan pinjaman langsung diolah oleh pihak koperasi sehingga mendapatkan nilai bobot pada setiap kuisioner yang pilih oleh nasabah yang mengajukan pinjaman, kemudian diproses dengan penelitian metode ANP yang menghasilkan nilai bobot dan perengkingan.

Terlihat pada tabel 11 diatas nilai limit supermatrik terdapat nilai perengkingan untuk setiap alternatif yang mengajukan pinjaman pada tabel tersebut terdapat perengkingan dengan peringkat pertama dengan nlai bobot 0.040 , peringkat kedua 0.002 dan peringkat ketiga 0.001 . dimana nilai bobot tersebut didapatkan dari hasil perbandingan subkriteria dan perbandingan alternatif terhadap subkriteria, jika nilai eigen vektore /nilai bobot dari perbandingan sudah didapatkan metode ANP menggunakan supermatrik untuk memproses nilai bobot tersebut yaitu nilai bobot dari perbandingan di masukan kedalam tabel nilai tidak berbobot / unweight supermatrik, setelah tersusun pada tabel unweigth supermatrik kemudian dikalikan dengan nilai bobot perbandingan anta kriteria pada tabel 4.1, dikalikan dengan pengaruh masing masing kriteria terhadap kriteria lain kemudian dari hasil perkalian unweight supermatrik dengan nilai bobbot perbandinngan menghasilkan nilai berbobot / weight supermatrik, nilai unweight supermatrik dikalikan dengan dirinya sendiri (dipangkatkan) secara terus menerus sampai nilai setiap kolom bernilai sama sehingga menghasilkan nilai batas / limit supermatrik.

Setelah dilakukan uji aplikasi dengan black box mendapatkan nilai presentasi yang dihasilkankan dari pengujian black box adalah $75 \%$ yang berarti bahwa software pada penelitian ini memenuhi standar kualitas.

\section{KESIMPULAN}

Metode ANP membandingkan setiap kriteria yang berhubungan dengan kriteria lain dan juga membandingkan kriteria yang mempengaruhi dirinya sendiri, kemudian membandingkan subkriteria sehingga mengashilkan nilai bobot yang di hasilakn dari nilai kepentingan kriteria terhadap kriteria lain kemudian diproses dengan tahapan penelitian metode ANP sehingga menghasilkan limit supermatrik / nilai batas yang nantinya dilakukan perengkingan untuk setiap alternatif yang digunakan, kemudian perengkingan tersebut akan menjadi pendukung keputusan pihak kepala khsususnya kepala koperasi untuk memberikan keputusan layak atau tidaknya menerima pinjaman dari koperasi. Nilai bobot yang di hasilkan dari penelitian metode ANP untuk semua kriteria, kriteria keuangan terdapat dua subkriteria pendapatan nilai bobot 0.170 , dan pengeluaran nilai bobot 0.10 . kemudian kriteria pekerjaan dengan subkriteria jabatan nilai bobot 0.029 , lama kerja nilai bobot 0.005 , dan status kerja nilai bobot 0.043 , untuk nilai bobot alternatif A1 nilai bobot 0.001 , alternatif A2 nilai bobot 0.040 dan alternatif A3 nilai bobot 0.002. Sistem pendukung keputusan pinjaman kredit anggota koperasi dengan metode ANP ini sangat layak untuk dijadikan acuan oleh pihak koperasi karna konsep penelitian yang dilakukan oleh metode ANP bersifat structure network dimana setiap kriteria yang digunakan saling berhubungan dan tidak terstrukture, kemudian hasil dari pengujian dengan black box software yang dibuat layak digunakan karna telah memenuhi standar dengan nilai presentasi yang didapatkan $75 \%$.

\section{DAFTAR PUSTAKA}

[1] Ninik Widiyanti \& Sunindhia. Koperasi dan Perekonomian Indonesia. Jakarta: Rineka Cipta, 2009

[2] Iwan Vanany, "Aplikasi Analytic Network Process (Anp) Pada Perancangan Sistem Pengukuran Kinerja”, Institut Teknologi Sepuluh Nopember, Surabaya, Jurnal Teknik Industri Vol. 5, No. 1, Juni 2003.

[3] Saaty, T.L. Decision Making with dependence and feedback: The Analytical Network Process. 1st ed. Pittsburgh, PA: RWS publication, 1996.

[4] Khairil Adnan, Sandy Eka Permana, Tineka Handayani ," Sistem Pendukung Keputusan Penentuan Pemberian Pinjaman Uang Dengan Metode Ahp (Analytic Hierarchy Process) Di Koperasi Simpan Pinjam Eka Muly" Sekolah Tinggi Manajemen Informatika Stmik (Ikmi) Cirebon, Jurnal Online Ict Stmik Ikmi - Vol.10 - Edisi Desember 2013. 
JURSISTEKNI (Jurnal Sistem Informasi dan Teknologi Informasi) Vol 2, No. 2, Mei 2020: Hal 25 - 38

ISSN. P: 2715-1875, E: 2715-1883

[5] Agung Triayudi , Fajar Setiawan Hidayat ,"Sistem Pendukung Keputusan Penentuan Penerima Pinjaman Modal Dana Bergulir Koperasi Simpan Pinjam Pada Diskoperindag Kabupaten Serang Menggunakan Metode Topsis” Jurnal ProTekInfo Vol. 3 No. 1 September 2016.

[6] Agusta Praba Ristadi Pinem,Prind Triajeng Pungkasanti Edi Widodo, "Implementasi Profile Matching Untuk Pemberian Kredit Kedua Pada Koperasi Simpan Pinjam” 2016.

[7] Igon, Irya Wisnubhadra, B.Yudi Dwiandiyanta, "Perancangan Sistem Pendukung Keputusan Dengan Metode Fuzzy Analytic Hierarchy Process Dalam Penyeleksian Pemberian Kredit" Universitas Atma Jaya Yogyakarta, Seminar Nasional Teknologi Informasi dan Komunikasi (SENTIKA 2014) ISSN: 2089-9813 Yogyakarta, 15 Maret 2014.

[8] Mulyono, Teguh Pudjo. Manajemen Perkreditan Komersil.Yogyakarta: BPFE, 2002.

[9] Pangestu, Danu Wira. Teori Dasar Sistem Informasi Manajemen (SIM). IlmuKomputer.com, 2007.

[10] O’Brien, James. Pengantar sistem Informasi : Perspektif Bisnis dan Manajerial, Edisi ke-12 terjemahan Dewi Fitiriasari dan Deny Arnos Kwary, Salemba Empat, Jakarta, 2005.

[11] Turban, Efraim et al and Little. Decision Support System and Intelligent System. Penerbit Andi : Yogyakarta. 2005.

[12] Saaty, T. L. Theory and Applications of the Analytic Network Process, Decision Making with Benefits, Opportunities, Costs, and Risks, RWS Publications, Pittsburgh, 2005.

[13] Pudji Astuti,et.al, Pemilihan Alternatif Pengelolaan Sampah Dengan Metode ANP dan Bocr .Universitas Trisakti Jakarta, Vol.VI. No 2. 2011.

[14] Saaty, T.L. (1999). Fundamentals of The Analytic Network Process. USA: University of Pittsburgh

[15] Saaty, Thomas L and Vargas, Louis G. Decision Making with the Analitic Network Process, Economic, Political, Social and Technological Applications with Benefits, Opportunities, Costs and Risks. Springer. RWS Publication, Pittsburgh, 2006. 